\title{
La campagne dans la campagne : pour la parité au sein des nouvelles assemblées autonomes
}

The campaign within the campaign: the fight for parity in the new devolved Assemblies

\section{Véronique Molinari}

\section{OpenEdition Journals}

Édition électronique

URL : http://journals.openedition.org/rfcb/1179

DOI : $10.4000 /$ rfcb. 1179

ISSN : 2429-4373

\section{Éditeur}

CRECIB - Centre de recherche et d'études en civilisation britannique

\section{Édition imprimée}

Date de publication : 2 janvier 2006

Pagination : 165-175

ISBN : 2-911580-23-0

ISSN : 0248-9015

\section{Référence électronique}

Véronique Molinari, «La campagne dans la campagne : pour la parité au sein des nouvelles assemblées autonomes », Revue Française de Civilisation Britannique [En ligne], XIV-1 | 2006, mis en ligne le 15 octobre 2016, consulté le 01 mai 2019. URL : http://journals.openedition.org/rfcb/1179 ; DOI : 10.4000/rfcb. 1179

\section{(c) (†) $\ominus$}

Revue française de civilisation britannique est mis à disposition selon les termes de la licence Creative Commons Attribution - Pas d'Utilisation Commerciale - Pas de Modification 4.0 International. 


\title{
The 1997 devolution referendums in Scotland and Wales
}

\author{
Nathalie DUCLOS \\ Université de Toulouse-Le-Mirail
}

Until recently, in Britain, referendums were seen as undermining the key constitutional principle of Parliament's supremacy and undivided sovereignty. The first referendum held on British soil was only organised in 1973 and the first and only British-wide referendum was held in 1975. While referendums are no longer considered as alien to the British system of government, they remain exceptional and are almost always concerned with changes in the status of the British nations and regions, as table 1 shows. Why are such constitutional changes now ratified by referendum? It seems that to British governments (or rather British Labour governments, as only the first referendum was organised by a Conservative government), the referendum is not so much a constitutional device as a political expedient. In the British Parliament, a Bill concerning proposals for one of the nations or regions which make up the UK is very likely to be rejected by MPs from the rest of the country wanting to safeguard their own interests and careful not to shift the balance of powers unfavourably. Referendums are therefore a way of legitimising and of strengthening governments' proposals, even in a context when the majority of the UK disagrees. This was one of the reasons given by the first Blair government for organising two referendums, a few months after Labour was elected in 1997, as promised in the party's electoral manifesto. The first was held in Scotland on 11 September 1997 and the second in Wales on 18 September 1997.

The existing literature on the 1997 Scottish and Welsh referendums has largely focused on each referendum separately, ${ }^{1}$ but has more rarely sought to compare the two, ${ }^{2}$ although they are obviously linked. This article seeks to compare the projects on offer, the referendum campaigns and the referendum results in Scotland and Wales.

\section{The referendum announcement: the spectre of 1979}

The 1997 referendums concerned Labour's devolution projects in Scotland and Wales, and as such, they echoed the failed 1979 devolution referendums, also

\footnotetext{
${ }^{1}$ Two articles on the 1997 Scottish referendum, as well as two articles on the 1997 Welsh referendum, are mentioned in the bibliography at the end of this article.

${ }^{2}$ The main exception is the following book: Bridget TAYLOR \& Katarina THOMSON (eds.), Scotland and Wales: Nations Again?, Cardiff: University of Wales Press, 1999.
} 
Table 1: Referendums in the UK

\begin{tabular}{|c|c|c|c|c|}
\hline Date & Area & Question & $\begin{array}{c}\text { 'Yes' } \\
\text { Votes \% }\end{array}$ & Turnout $\%$ \\
\hline $\begin{array}{c}8 \\
\text { March } \\
1973\end{array}$ & $\begin{array}{l}\text { Northern } \\
\text { Ireland }\end{array}$ & $\begin{array}{l}\text { (i) Do you want NI to remain part of the } \\
\text { UK? or } \\
\text { (ii) Do you want NI to be joined with } \\
\text { the Republic of Ireland, outside of the } \\
\text { UK? }\end{array}$ & 98.9 & 58.7 \\
\hline $\begin{array}{c}5 \text { June } \\
1975\end{array}$ & UK & $\begin{array}{l}\text { Do you think that the UK should stay in } \\
\text { the European Community (The } \\
\text { Common Market)? }\end{array}$ & 67.2 & 64.5 \\
\hline $\begin{array}{c}1 \\
\text { March } \\
1979\end{array}$ & Scotland & $\begin{array}{l}\text { Do you want the provisions of the } \\
\text { Scotland Act to be put into effect? }\end{array}$ & 51.6 & 63.6 \\
\hline $\begin{array}{c}1 \\
\text { March } \\
1979\end{array}$ & Wales & $\begin{array}{l}\text { Do you want the provisions of the } \\
\text { Wales Act } 1978 \text { to be put into effect? }\end{array}$ & 20.9 & 58.8 \\
\hline $\begin{array}{l}11 \\
\text { Sept. } \\
1997\end{array}$ & Scotland & $\begin{array}{l}\text {-Q1: (i) I agree that there should be a } \\
\text { Scottish Parliament; or } \\
\text { (ii) I do not agree that there should be a } \\
\text { Scottish Parliament } \\
\text {-Q2: (i) I agree that a Scottish } \\
\text { Parliament should have tax-varying } \\
\text { powers; or } \\
\text { (ii) I do not agree that a Scottish } \\
\text { Parliament should have tax-varying } \\
\text { powers. }\end{array}$ & 63.5 & 60.1 \\
\hline $\begin{array}{c}18 \\
\text { Sept. } \\
1997\end{array}$ & Wales & $\begin{array}{l}\text { (i) I agree that there should be a Welsh } \\
\text { Assembly; or } \\
\text { (ii) I do not agree that there should be a } \\
\text { Welsh Assembly }\end{array}$ & 50.3 & 51.3 \\
\hline $\begin{array}{c}7 \text { May } \\
1998\end{array}$ & $\begin{array}{l}\text { Greater } \\
\text { London }\end{array}$ & $\begin{array}{l}\text { Are you in favour of the Government's } \\
\text { proposals for a Greater London } \\
\text { Authority, made up of an elected mayor } \\
\text { and a separately elected assembly? }\end{array}$ & 72.0 & 34.0 \\
\hline $\begin{array}{c}22 \text { May } \\
1998\end{array}$ & $\begin{array}{l}\text { Northern } \\
\text { Ireland }\end{array}$ & $\begin{array}{l}\text { Do you support the agreement reached } \\
\text { at the multi-party talks on Northern } \\
\text { Ireland and set out in Command Paper } \\
3883 \text { ? }\end{array}$ & 71.1 & 81.0 \\
\hline $\begin{array}{l}5 \text { Nov. } \\
2004\end{array}$ & $\begin{array}{l}\text { North East } \\
\text { England }\end{array}$ & $\begin{array}{l}\text { Should there be an elected assembly for } \\
\text { the North East region? }\end{array}$ & 22.1 & 77.9 \\
\hline
\end{tabular}

organised under a Labour government. That is why the announcement on 27 June 1996 that there would be new devolution referendums caused such furore in these nations, especially in Scotland where, most unusually, not one but two questions were to be put to the electorate: one on the establishment of a Parliament and the other on the Parliament's fiscal powers. Labour had previously said that an election victory would be enough to set up a Scottish Parliament and a Welsh Assembly, these policies being mentioned in their 1997 manifesto. Pro-devolutionists therefore suspected that the need for referendums was a Labour ploy to ensure the failure of the devolution projects. Many of them were also livid at not having been consulted 
and felt that the decision had been imposed on them by Tony Blair. In Scotland, two leading autonomists, namely Harry Ewing, the former co-chairman of the Scottish Constitutional Convention, and John McAllion, the shadow minister in charge of devolution, even resigned from their positions in protest. Ron Davies, the Welsh Secretary of State, was particularly embarrassed because he had explicitly ruled out the possibility of a referendum in the Western Mail, a Welsh morning paper, a few days before the annoucement. There was talk that it was in fact George Robertson, the Shadow Scottish Secretary, who convinced Tony Blair of the need for a referendum in Scotland, for reasons that will be expounded later, and that if Scotland was to have a referendum, then Wales would have to have one too. What is likely is that the decision was made irrespective of the Welsh situation and without the knowledge of the Welsh Secretary and the Wales Labour Party.

The pro-devolutionists' anger was understandable: the failure of the 1979 referendums had not only hastened Labour's fall, inaugurating an eighteen-year-long era of Conservative rule, but it had also put devolution off the political agenda for a decade. Yet they need not have feared: the 1997 referendums were victories for the 'Yes' camps in both Scotland and Wales. Why did nations who had rejected devolution in 1979 vote for it in 1997? By the time the second Scottish and Welsh referendums were organised, devolution had become a much more consensual issue in both nations. Four reasons are generally given for this. First of all, eighteen years of Conservative rule and Thatcherite policies had convinced the mainly Labourvoting populations of Scotland and Wales that there was a 'democratic deficit' in Britain which only the creation of local assemblies could make good. Secondly, the 1997 referendums, which took place in the aftermath of Labour's landslide election, were held in a very different context from the 1979 referendums, which had been organised by the weak Callaghan government. This meant that the 1997 Labour government was not held to ransom by rebel Labour MPs as the 1979 Labour government had been. Thirdly, the pro-devolutionists were much more united the second time round, as a quick comparison between the 1979 and 1997 referendum campaigns will show. Finally, the 1979 referendums had been post-legislative and had concerned the precise devolution projects contained in the 1978 Scotland Act and the 1978 Wales Act. The questions put to the Scottish and Welsh people had been 'Do you want the provisions of the Scotland Act to be put into effect?' and 'Do you want the provisions of the Wales Act 1978 to be put into effect?' The 1997 referendums were on the contrary pre-legislative and aimed at gathering the Scottish and Welsh people's opinions on general principles. In 1997, the Welsh were asked whether they agreed or disagreed 'that there should be a Welsh Assembly'. The Scottish people were similarly asked whether they agreed or disagreed 'that there should be a Scottish Parliament', and also whether they agreed or disagreed 'that a Scottish Parliament should have tax-varying powers'.

\section{The projects on offer}

Although the Scottish and Welsh people were asked very general questions of principle, agreeing to these principles meant accepting precise devolution projects set out in two White Papers published in July 1997, which later became the basis for the Scotland Act 1998 and the Government of Wales Act 1998, but were themselves based on previously drafted proposals. Here the Scottish and Welsh cases differ. Not 
only were the Scottish and Welsh devolution projects quite different, despite the obvious fact that in both nations, the general aim was the creation of a national Assembly or Parliament, but they had also been drawn up in very different contexts. In the Scottish case, they had been carefully drafted by the widely representative, cross-party Scottish Constitutional Convention, whereas in the Welsh case they were the product of internal discussions within the Wales Labour Party.

The Scottish Constitutional Convention met for the first time on 30 March 1989 and published two reports, Towards Scotland's Parliament in 1990 and Scotland's Parliament, Scotland's Right in 1995. It was jointly chaired by a Liberal Democrat (Sir David Steel, the former leader of the Scottish Liberal Democrats) and a Labour MP (Harry Ewing, a former minister). It was made up of a wide crosssection of Scottish society. There were elected representatives - MPs, MEPs and local councillors - and party delegates from two major parties, Labour and the Liberal Democrats, and five smaller parties or movements, mainly the Greens and the Communists. Other members represented Scotland's civil society: its trade unions, churches, small businesses, women's movements or ethnic minority communities. The SNP and the Conservatives, the two parties most opposed to devolution, were notably absent at the Convention, but the Convention's second report claims that 'many individuals from both these parties have supported [their] work publicly or privately,. The main points in the Convention's reports and in the subsequent White Paper entitled Scotland's Parliament were that there should be a Scottish Parliament, that it should be a single-chamber legislature made up of 129 members (73 constituency representatives and 56 additional members chosen by proportional representation) with a fixed term of four years, and that it should have wide legislative powers but very restricted tax powers. The Parliament would legislate in all areas for which the Scottish Secretary of State had been responsible and it would have the power to increase or cut the basic rate of income tax by up to 3 pence in the pound.

Labour's plans for devolution to Wales, while similar to its plans for Scotland, were much less ambitious. Its White Paper on Wales, entitled A Voice for Wales, suggested that there should be a Welsh Assembly with 60 members (40 constituency representatives and 20 additional members chosen by proportional representation) with a fixed term of four years. The Assembly would take over the responsibilities of the Secretary of State for Wales concerning policies and public services in Wales, but these were less extensive than the Scottish Secretary's. Moreover, the Assembly would only have secondary legislative powers, meaning powers over the 'orders, rules and regulations which fill in the details of the framework set in Acts of Parliament' voted at Westminster. ${ }^{4}$ Labour's plans for Welsh devolution had already been outlined in two internal reports, Shaping the Vision and Preparing for a New Wales, respectively drafted for the May 1995 and the May 1996 Wales Labour Party Conferences. But calls by the Wales TUC (Trades Union Congress) for a Constitutional Convention on the Scottish model were rejected by the Wales Labour

\footnotetext{
${ }^{3}$ Scottish Constitutional Convention, Scotland's Parliament, Scotland's Right, Edinburgh: Scottish Constitutional Convention, 1995, p. 9.

${ }^{4}$ GREAT BRITAIN WELSH OFFICE, A Voice for Wales, Cm.3718, London: H.M.S.O., 1997, p. 24.
} 
Party and the Wales Parliamentary Labour group, for two reasons. A Convention would have meant bringing in Plaid Cymru, and a Convention would have raised the divisive issue of electoral reform. At the time of the Wales Labour Party's first report on devolution, proportional representation had not been included in the blueprint. It was approved by the Party Executive in January 1997, after it became obvious that this was the only way to win round the other parties to the devolution project. From then on, the main differences between the Scottish and Welsh proposals were the extent of the legislative powers envisaged for each assembly and the Scottish Parliament's planned fiscal powers.

It was on the principles presented in the two July 1997 White Papers that the Scottish and the Welsh people were asked to vote on the days of the referendums. But why did the Welsh referendum contain one question only, on the general principle of devolution, while the Scottish referendum contained two, the Scottish public being asked to vote both on the principle of devolution and on a precise part of the devolution package, namely the Scottish Parliament's fiscal powers? The answer has to do with realpolitik and with differences in the Scottish and Welsh political contexts. First of all, it seems that it was the Scottish Labour Party which insisted on settling the issue of the Parliament's tax-varying powers by referendum as a compromise position between Tony Blair's opposition to the Parliament having such powers and the position of the Scottish Constitutional Convention, which believed they were essential in order to give the Parliament greater independence from Westminster. Secondly, in Scotland, opponents to devolution had chosen to concentrate their attacks on the taxation powers. After Labour had agreed to the introduction of some element of proportional representation, the question of the Parliament's fiscal powers had been the only part of the devolution package still open to controversy. Since 1995, when Michael Forsyth had become Secretary of State for Scotland, the Conservatives had warned that granting the Scottish Parliament such powers would lead to the creation of an extra 'tartan tax' for the Scottish public. This is the kind of allegation which New Labour, desperate to shed the party's old 'tax-and-spend' image, could not afford to ignore. The Scottish Labour Party was therefore compelled by the London Party Executive to promise that if it became the majority party in the Scottish Parliament, it would not resort to the taxation powers for the duration of the first parliamentary session. Putting those powers to referendum was another way of undermining the Conservatives' position as Labour could argue that the Scottish people were not being made to accept anything they had not agreed to. In Wales, where the devolution proposals were less extensive, there was no question of the Assembly having primary legislative powers, let alone fiscal powers. There was therefore no need to jeopardise the outcome of the referendum even more by asking the Welsh extra questions on specific aspects of the proposals.

\section{The referendum campaigns}

When the referendum campaigns began, the parties had learnt the lessons of the 1979 experience, especially on the 'Yes' side. In 1979, both 'Yes' and 'No' camps had been split, largely because of divisions within Labour, where vocal antidevolutionists had campaigned against party policy and where even the prodevolutionists had often lacked conviction and had refused to join forces with the 
nationalist parties and the pro-devolutionary Conservative minority. As a result, in Wales, alongside the two umbrella campaigns (the 'Wales for Assembly Campaign' on the 'Yes' side and the Conservative-dominated 'No Assembly Campaign' on the 'No' side), there had been a joint Labour-Wales TUC 'Yes' campaign and a 'Labour No Assembly Campaign', led by Labour backbenchers. Similarly, in Scotland, on the 'Yes' side, Labour had refused to run a joint campaign with the SNP and even a small 'Conservative Yes Campaign' had been established. On the 'No' side, although the Conservative Party had been the only party to campaign officially against the Assembly, a 'Labour No Campaign' had been launched alongside the campaign by 'Scotland Says No', a cross-party, Conservative-dominated body. After 1979, the 'Yes' camp in particular had felt that its internal divisions had been one of the main reasons behind the failure of the referendums. In 1997, the prodevolutionists were therefore determined to run cross-party and non-party campaigns.

In Scotland, a neutral umbrella group campaigning for a double 'Yes' vote (to the first and second questions), which went under the name 'Scotland Forward', was set up immediately after the May 1997 general election. The campaign was chaired by Nigel Smith, a businessman who was not affiliated to any party. It was supported by many non-party members as well as members of the three main Scottish parties, namely Labour, the Liberal Democrats and the SNP. Within Scottish Labour, leftwingers and nationalists opposed to the second question - such as Scottish Labour Action, a devolutionist pressure group - were soon silenced by Blair loyalists. Although they were opposed to a referendum, the Scottish Liberal Democrats had no choice but to join the cross-party campaign, especially since their role within the Scottish Constitutional Convention had allowed them to contribute significantly to the devolution proposals. They were especially satisfied with two elements of the devolution scheme: proportional representation and the Parliament's tax-varying powers. That the SNP should give its support was less obvious, as the Nationalists had withdrawn from the Scottish Constitutional Convention at a very early stage. There were some within the party who believed that their first aim should be to campaign for independence, not devolution, and that they had not gained anything from campaigning for devolution in 1979. Yet in August 1997, the party's national council voted to join the 'Yes/Yes' campaign. The campaign was therefore backed by all the parties that represented Scotland at Westminster and by many high-profile figures such as Sean Connery. Scottish Labour leader Donald Dewar, Scottish Liberal Democrat leader Jim Wallace and SNP leader Alex Salmond were shown sharing platforms for the first time. The 'Yes' campaign turned on four quintessentially Labour themes: "that the referendum was a battle pitching Scotland against the Tories, that the Scottish parliament was essentially a new Labour government project to fulfil Tony Blair's aim of modernising Britain, that there would be no tax rises and that the parliament would mean Scots taking decisions on Scottish issues in Scotland. ${ }^{5}$ On the contrary, the Scottish 'No' campaign, known as 'Think Twice' and launched in late June 1997, was lacklustre and weak. As the business community largely kept out of the campaign, the main backing for it came from the Conservatives, who had not returned a single Scottish MP at the general

5 Peter JONES, 'A Start to a New Song: the 1997 Devolution Referendum Campaign', Scottish Affairs, vol. 21, 1997, p. 9. 
election. The campaign was run by Lord Fraser, a former Scottish Office minister, but it could not boast the support of any celebrity personality. Moreover, the antidevolutionists were divided between 'No/No' supporters, 'No/Yes' supporters people who were against a Parliament but thought that if there was to be one, then it should have fiscal powers - and even 'Yes/No' supporters, mainly businessmen who were in favour of a Scottish Parliament but were against paying higher taxes. The 'No' campaign did not reap any benefits from Margaret Thatcher's visit to Scotland two days before the referendum - quite the reverse, it seems: that day, the Daily Record, the leading Scottish tabloid, featured a picture of her on its front page, along with the words: 'If you still need a reason to vote Yes: here's one. ${ }^{6}$ The other highprofile intervention in favour of the 'No' camp came from Sir Bruce Patullo, governor of the Bank of Scotland. In an interview with The Scotsman, he said that the bank did not wish to comment on the desirability of a Scottish Parliament, but that it opposed the Parliament's fiscal powers, which it believed would be bad for jobs and the health of the Scottish economy. ${ }^{7}$ The 'No/No' supporters knew that they were fighting a lost cause on the first question and that the only way of thwarting Labour's devolution plans was to secure a majority of 'No' votes on the second question. Their campaign was thus focused on one issue: the cost of devolution. When all campaigning was suspended for a week just before the referendum out of respect for Lady Diana, who had died on 30 August 1997, some feared that this would be more detrimental to the 'Yes' camp than to the 'No' camp. There was some speculation that the emotion caused by her death would lead to an upsurge in feelings of Britishness and to the people rejecting any plan that could jeopardise the British Union. But the campaign for a Scottish Parliament had been going on for at least a decade and was not to be undone by an isolated event, tragic though it was.

The Welsh situation was rather different. It was always far from obvious that the 'Yes' camp would win. There had been no high-profile, cross-party, nine-yearlong Constitutional Convention, meaning that none of the parties likely to call for a 'Yes' vote had ever worked together and that the Welsh public was little aware of, or interested in, Labour's devolution plans. Moreover, Labour still faced internal divisions over devolution to Wales. Many within the party were hostile, some of whom were prominent figures in local government, especially in Cardiff. The debates on the Referendum (Scotland and Wales) Bill had enabled Labour antidevolutionists to voice their opposition ahead of the referendum campaign. But in the context of Labour's huge majority in the House of Commons, Labour dissidents held much less power than their 1979 predecessors. More importantly, the party generally appeared to be more committed to devolution to Wales than in 1979, as both the Wales Labour Party and (after 1 May 1997) the Labour government campaigned for an Assembly, though there were tensions between the two. Labour also took part in the cross-party 'Yes for Wales' campaign which was officially launched in February 1997. The campaign included members of Welsh civil society, such as trade unionists and academics, alongside members of the Wales Labour Party, the Welsh Liberal Democrats and Plaid Cymru, the three Welsh parliamentary

${ }^{6}$ Quoted in Lindsay PATERSON, A Diverse Assembly. The Debate on a Scottish Parliament, Edinburgh: Edinburgh University Press, 1998, p. 227.

${ }^{7}$ The Scotsman, 22 August 1997, mentioned in Peter JONES, op.cit., p. 11. 
parties. This unity was largely the result of one man's efforts. Ron Davies, who was Shadow Welsh Secretary at the beginning of the campaign and became Welsh Secretary after the May 1997 general election, had previously secured the backing of Plaid Cymru and the Welsh Liberal Democrats for Labour's devolution plans by adding an element of proportional representation to the original Labour blueprint for an Assembly. Plaid Cymru, in particular, had at first been opposed to Labour's planned referendum and had argued instead for a multi-choice 'preferendum' in which the people could choose to vote for independence. Like the SNP, it was deeply scarred by the 1979 referendum campaign, when it had done most of the work in support of Labour's proposals. Therefore it only endorsed the new devolution proposals and agreed to take part in the cross-party campaign in mid-July 1997, when it felt that the Wales Labour Party's commitment was secure enough. A lot of grassroots members also believed that devolution was better than the status quo and that the opportunity to influence the course of Welsh politics should not be missed. The Liberal Democrats had long been committed to home rule and there were no public divisions within the party over devolution. Unlike their Scottish counterparts, the Welsh Conservatives had never in their history supported any plan to establish an autonomous Assembly. They were therefore the backbone of the 'Just Say No' campaign, which existed alongside Labour dissenters' personal 'No' campaigns. The 'Just Say No' campaign was officially launched on 21 July 1997, the day before the government published its White Paper on Wales. It was very lowkey, as the Welsh Conservatives were demoralised, having just been eliminated as a parliamentary force. The 'No' camp's main arguments were based on voters' fears: fears of increased costs and bureaucracy, fears of breaking the Union, and even nonWelsh speakers' fears regarding the place of the Welsh language. The 'Yes for Wales' campaign had a much higher profile and was focused on the general principles of devolution. Yet it is difficult to make generalisations about the 'Yes' campaign in Wales, as it was not nation-wide: on the contrary, there were locally based campaigns with different messages according to the area covered. Labour concentrated its efforts on convincing voters in its traditional heartlands, namely the mining valleys and industrial centres of South Wales, whereas in parts of North Wales for example, Plaid Cymru members worked for the 'Yes' campaign.

The Scottish and Welsh referendum campaigns had quite a lot in common. The Scottish 'Yes' camp included both members of Scotland's civil society and members of the three main Scottish parties; the campaign was high-profile and widely covered by the national media. The 'No' camp was weak and divided, and its only real support came from a party which had just been wiped out at the general election. In Wales, the 'Yes' camp was also widely representative and included the three Welsh parliamentary parties, while the 'No' camp was mainly restricted to the Conservatives, though there were more Labour dissenters than in Scotland. Yet the Scottish and Welsh campaigns did not revolve around the same issues: the Scottish one was essentially centred on the question of tax rises, whereas the Welsh one raised more general questions to do with the principle of devolution. But the main difference between the two campaigns lies in the extent of press coverage of, and support for, the 'Yes' sides. Press coverage of the Scottish 'Yes' campaign was very wide because of the many celebrities involved, and more importantly, because the campaign had the support of all the Scottish dailies, even right-wing papers such as The Daily Express; the only exception was the Daily Mail. This was a great asset for 
the 'Yes' side, as the vast majority of Scottish people read Scottish dailies or Scottish editions of British dailies. In Wales, most people read British newspapers, which are unlikely to cover Welsh events extensively. This proved true during the referendum campaigns. So although the two Welsh morning papers, the Cardiffbased Western Mail and the Liverpool-based Daily Post, advocated a 'Yes' vote, the public was less aware of the 'Yes' arguments than in Scotland.

\section{The referendum results}

Table 2: Results of the 1979 and 1997 devolution referendums, Scotland and Wales (\% of the votes)

\begin{tabular}{|l|c|c|c|c|c|}
\hline & \multicolumn{3}{|c|}{ Scotland } & \multicolumn{2}{c|}{ Wales } \\
\cline { 2 - 6 } & 1979 & $1997(\mathrm{Q} 1)$ & $1997(\mathrm{Q} 2)$ & 1979 & 1997 \\
\hline \% Yes & 51.6 & 74.3 & 63.5 & 20.3 & 50.3 \\
\% No & 48.4 & 25.7 & 36.5 & 79.7 & 49.7 \\
\hline \% Turnout & 63.6 & $\mathbf{6 0 . 4}$ & $\mathbf{6 0 . 4}$ & $\mathbf{5 8 . 8}$ & 50.1 \\
\hline
\end{tabular}

Table 3: 1979 and 1997 referendums in Scotland: results by region (\% of the votes)

\begin{tabular}{|l|c|c|c|}
\hline Region & $\begin{array}{c}\mathbf{1 9 7 9} \\
\text { \% Yes }\end{array}$ & $\begin{array}{c}\mathbf{1 9 9 7} \\
\text { \% Yes Q1 }\end{array}$ & $\begin{array}{c}\mathbf{1 9 9 7} \\
\text { \% Yes Q2 }\end{array}$ \\
\hline Borders & 40,3 & 62,8 & 50,7 \\
\hline Central & 54,7 & 76,3 & 65,9 \\
\hline $\begin{array}{l}\text { Dumfries \& } \\
\text { Galloway }\end{array}$ & 40,3 & 60,7 & 48,8 \\
\hline Fife & 53,7 & 76,1 & 64,7 \\
\hline Grampian & 48,3 & 67,6 & 55,6 \\
\hline Highland & 51,0 & 72,6 & 62,1 \\
\hline Lothians & 50,1 & 74,5 & 63,7 \\
\hline Orkney & 17,9 & 57,3 & 47,4 \\
\hline Shetland & 27,1 & 62,4 & 51,6 \\
\hline Strathclyde & 54,0 & 78,1 & 67,7 \\
\hline Tayside & 49,5 & 67,6 & 57,0 \\
\hline Western Isles & 55,8 & 79,4 & 68,4 \\
\hline SCOTLAND & 51,6 & 74,3 & 63,5 \\
\hline
\end{tabular}

Regardless of the differences in the referendum campaigns, in the end, both Scotland and Wales voted for devolution. But here again it would be misleading to lump the two nations together: the scale of the 'Yes' victory makes the Scottish results very different from the Welsh ones. While the devolution plans were agreed to by a resounding majority of the Scottish people, they only got the backing of the slightest of majorities in Wales. 
Table 4: 1979 and 1997 referendums in Wales: results by county (\% of the votes)

\begin{tabular}{|l|c|c|}
\hline County & $\begin{array}{c}\mathbf{1 9 7 9} \\
\text { \% Yes }\end{array}$ & $\begin{array}{c}\mathbf{1 9 9 7} \\
\text { \% Yes }\end{array}$ \\
\hline Clwyd & 21.6 & 41.2 \\
\hline Dyfed & 28.1 & 57.1 \\
\hline Gwent & 12.1 & 42.5 \\
\hline Gwynedd & 34.4 & 52.9 \\
\hline Mid Glamorgan & 20.2 & 56.4 \\
\hline Powys & 18.4 & 42.7 \\
\hline South Glamorgan & 13.1 & 41.8 \\
\hline West Glamorgan & 18.7 & 57.7 \\
\hline WALES & 20.3 & 50.3 \\
\hline
\end{tabular}

As tables 2 and 3 reveal, in Scotland, on a turnout of $60.4 \%$, three-quarters of the people voted in favour of a Scottish Parliament and almost two-thirds voted in favour of it having tax-varying powers. The majority was more restricted on the second question than on the first; yet it was higher than most had predicted, since the taxation powers had been interpreted as powers to raise taxes, not to lower them. The Conservatives had also focused their attacks on this aspect of the devolution package, which they had felt to be its weakest. Moreover, all 12 regions (and all 32 local government areas) supported the creation of a Scottish Parliament and only two regions, Orkney and Dumfries \& Galloway, voted 'No' to the second question.

A comparison between those results and the 1979 results shows to what extent support for devolution had increased in 18 years. In 1997, 74.3\% of Scottish voters wanted a Scottish Parliament to be established; this was $22.7 \%$ more voters than in 1979, when $51.6 \%$ of them had agreed to the creation of a Scottish Assembly. Consensus over devolution had also spread throughout Scotland. In 1979, only half the regions (6 out of 12) had voted in favour of a Scottish Assembly, with as little as $27.1 \%$ of the people in Shetland and $17.9 \%$ of the people in Orkney voting 'Yes'; the best 'Yes' results had been 55.8\%, obtained in the Western Isles. By contrast, in 1997, even Orkney and Shetland agreed to the establishment of a Scottish Parliament. The lowest regional 'Yes' vote on the first question was $57.3 \%$ (in Orkney again) and the highest was $79.4 \%$ (in the Western Isles again).

There had only been one question in the 1979 referendum, so that the 1997 results on the second question can be compared to no other. Nevertheless, it is remarkable that even in the two regions which voted against the tax powers in 1997, there was not a decisive majority of 'Noes': $47.4 \%$ of the people in Orkney and $48.8 \%$ of the people in Dumfries \& Galloway still voted 'Yes'. As for turnout, it was lower in 1997 than in 1979 (60.4\% compared with 63.6\%), but some in the 'Yes' camp believe that the real turnout was closer to $71 \%$, as the electoral register was 11 months out of date, 6 months more than the 1979 register, so that an estimated $15 \%$ of the people on the electoral roll had died or moved at the time of the referendum. ${ }^{8}$ More importantly, the turnout and the 'Yes' margin were enough for $44.7 \%$ of the electorate to vote for a

${ }^{8}$ Peter JONES, op. cit., p. 2. 
Scottish Parliament. In 1979, an amendment to the Scotland Act 1978, called the Cunningham amendment, had ensured that a Scottish Assembly would only be set up if not only more than $50 \%$ of the voters, but also more than $40 \%$ of the total electorate agreed to it in the forthcoming referendum. So even though more than half the Scottish voters $(51.6 \%)$ had voted 'Yes', this had only represented $32.8 \%$ of the electorate and the devolution plans had been abandoned. In 1997, a simple majority of those voting had been the majority required, as promised in the 1997 Labour manifesto, ${ }^{9}$ but it was quite heartening for the 'Yes' camp to know that more than $40 \%$ of the electorate had voted in favour of a Scottish Parliament anyway. In Scotland, the 1997 referendum confirmed that a national Parliament was indeed the 'settled will of the Scottish people', in John Smith's famous phrase.

By contrast, in Wales, the results seem to suggest a country deeply divided on the issue of devolution. Out of a turnout of only half the population $(50.1 \%$ of the electorate), only half the Welsh voters $(50.3 \%)$ came out in favour of a Welsh Assembly. In fact there was a 'Yes' majority of less than 7,000 votes out of a million votes cast $(559,419$ people voted 'Yes' and 552,698 people voted 'No'). This corresponded to as little as $0.6 \%$ of the votes and $0.3 \%$ of the electorate. Moreover, only half the councils (4 out of 8 , as table 4 shows) and half the local authority areas (11 out of 22) agreed to the creation of a Welsh Assembly.

These results, though much less decisive for the 'Yes' camp than in Scotland, were still a considerable improvement on the 1979 results and revealed a greater swing towards devolution than in Scotland. In 1997, 30\% more of the Welsh electorate voted 'Yes' than had voted 'Yes' in 1979, as opposed to $22.7 \%$ more of the Scottish electorate (on the first question). So why were the overall results so close in Wales? The geography of the vote seems to confirm that there is an EastWest divide in Wales. All of the Western districts voted 'Yes' apart from the most Western of them all, Pembrokeshire, whereas all of the districts bordering England voted 'No'. The city of Swansea voted 'Yes', but the city of Cardiff - which now hosts the Welsh Assembly - voted 'No'. These geographical divisions echo both socio-economic divisions, and cultural and linguistic divisions. The mainly Englishspeaking, more affluent parts of Wales, namely the Eastern coastal areas and the borderlands, voted 'No', while the industrial areas and mining valleys of the South, and the Welsh-speaking heartland of the North and West, voted 'Yes'. Table 5 shows that there was a significant relationship between voting 'Yes' and being able to speak Welsh.

Table 5: 1997 Welsh referendum: Language spoken and referendum vote

\begin{tabular}{|l|c|c|}
\hline Language & Yes (\%) & No (\%) \\
\hline Fluent Welsh & 77 & 23 \\
\hline Non-fluent Welsh & 48 & 52 \\
\hline No Welsh & 42 & 58 \\
\hline
\end{tabular}

Source: J. Barry JONES \& Denis BALSOM, The Road to the National Assembly for Wales, Cardiff: University of Wales Press, 2000, p.171.

${ }^{9}$ LABOUR PARTY, Because Britain Deserves Better, London: Labour Party, 1997, p. 33. 
A huge majority of fluent Welsh speakers voted 'Yes', whereas a majority of non-fluent Welsh speakers and of non-Welsh speakers voted 'No'. There was also a clear relationship between feelings of national identity and voting behaviour, but this was less true in Wales than in Scotland. Table 6 is based on the results of the 1997 Scottish and Welsh Referendum Studies, carried out in Scotland and Wales at the time of the referendums. People were asked whether they felt exclusively Scottish or Welsh, more Scottish / Welsh than British, equally Scottish / Welsh and British, or exclusively British; they were then asked how they had voted in the referendum.

Table 6: 1997 Scottish and Welsh referendums: National identity and referendum vote

\begin{tabular}{|l|c|c|c|c|c|c|}
\hline & \multicolumn{3}{|c|}{ Wales } & \multicolumn{3}{c|}{ Scotland } \\
\hline $\begin{array}{l}\text { Feelings of national } \\
\text { identity }\end{array}$ & $\begin{array}{c}\text { Yes } \\
(\%)\end{array}$ & $\begin{array}{c}\text { No } \\
(\%)\end{array}$ & $\begin{array}{c}\text { Did } \\
\text { not } \\
\text { vote } \\
(\%)\end{array}$ & $\begin{array}{c}\text { Yes } \\
(\%)\end{array}$ & $\begin{array}{c}\text { No } \\
(\%)\end{array}$ & $\begin{array}{c}\text { Did } \\
\text { not } \\
\text { vote } \\
(\%)\end{array}$ \\
\hline Welsh/Scottish, not British & 43 & 23 & 34 & 67 & 6 & 27 \\
\hline $\begin{array}{l}\text { More Welsh/Scottish than } \\
\text { British }\end{array}$ & 44 & 25 & 32 & 60 & 11 & 29 \\
\hline $\begin{array}{l}\text { Equally Welsh/Scottish and } \\
\text { British }\end{array}$ & 26 & 34 & 41 & 44 & 33 & 23 \\
\hline $\begin{array}{l}\text { More British than } \\
\text { Welsh/Scottish }\end{array}$ & 16 & 37 & 47 & 41 & 34 & 26 \\
\hline British, not Welsh/Scottish & 13 & 45 & 42 & 25 & 49 & 27 \\
\hline
\end{tabular}

Source: Bridget TAYLOR \& Katarina THOMSON (eds.), Scotland and Wales: Nations Again?, Cardiff: University of Wales Press, 1999, p.129.

In Wales, people who felt strongly Welsh (either just Welsh, or more Welsh than British) were those most likely to have voted 'Yes' in the referendum; they were also those least likely to have voted 'No'. Those two categories voted 'Yes' in almost equal numbers (43\% for the first category and $44 \%$ for the second). The less Welsh the people felt, the less likely they were to have voted 'Yes': more people who felt equally Welsh and British voted 'Yes' than people who felt more British than Welsh, and more people in this category voted 'Yes' than people who felt exclusively British.

Conversely, the weaker the respondents' feelings of Welsh identity, the more they were likely to have voted 'No'. The people who felt just Welsh were three times more likely to have been 'Yes' voters than the people who felt just British. Finally, there was a relationship between feelings of national identity and turnout: the people who felt strongly Welsh had lower levels of abstention than those who felt strongly British or who felt equally British and Welsh. But feeling Welsh was clearly not enough to guarantee a 'Yes' vote: even amongst the most strongly Welsh group, only $43-44 \%$ voted 'Yes' and up to $25 \%$ voted 'No'; one third did not vote at all. 
In Scotland, there was also a clear relationship between national identity and vote. As in Wales, the more Scottish people felt, the more likely they were to have voted 'Yes' and the less Scottish they felt, the more likely they were to have voted 'No'. What was different in the Scottish case was that there was no correlation between national identity and turnout: those who felt exclusively Scottish were just as likely to have voted than those who felt exclusively British. But the main difference was in the extent to which the strongly Scottish group voted 'Yes', compared with the equivalent group in Wales: $67 \%$ of those who felt just Scottish voted 'Yes', compared with $43 \%$ in Wales, and $60 \%$ of those who described themselves as more Scottish than British voted 'Yes', compared with $44 \%$ in Wales. Only $6 \%$ of those who felt just Scottish, and $11 \%$ of those who felt more Scottish than British, voted 'No', compared with $23 \%$ and $25 \%$ in Wales. So the more strongly Scottish group was markedly more in favour of devolution than the corresponding group in Wales. A comparison between the Welsh case and the Scottish case shows that the national identity variable is undoubtedly useful to explain differences in voting behaviour, but that it applies better to the Scottish model than to the Welsh one.

\section{Conclusion}

Since the birth of the Scottish and Welsh home rule movements at the turn of the $19^{\text {th }}$ and $20^{\text {th }}$ centuries, the constitutional destinies of the two nations have been linked. Home Rule Bills and official reports on devolution have often concerned both Scotland and Wales. The first two referendums on the establishment of Scottish and Welsh Assemblies were held the same day. Therefore it was not surprising that the decision to hold a new referendum in Scotland in 1997 led to another referendum being held in Wales. Yet the parallelism between the two nations must not obscure the marked differences between them, which the referendum campaigns and results highlighted. First of all, it is important to note that the movement for constitutional reform was initiated by Scotland, not Wales. In Wales, the debate on devolution was mainly restricted to Labour ranks, and the movement for devolution in the Labour Party was largely driven not by a desire for a Welsh Assembly, but by the Scottish Constitutional Convention. This explains why the devolution proposals were more extensive, and why the public was better informed about them, in Scotland than in Wales. This in turn explains why there was a one-question referendum in Wales and a two-question referendum in Scotland, and why the campaigns took place in very different contexts. In Scotland, the 'No' camp focused on the second question, as it knew it would not win on the first, whereas in Wales, it developed more general themes because it had every chance of winning. Different devolution schemes and different referendum campaigns gave different results. The Scottish people demanded a Parliament, while the Welsh only gave the Assembly grudging support. But in both Scotland and Wales the pro-devolutionists hailed the referendums as landmarks in the histories of their nations, as they represented the first concrete steps towards the establishment of the Scottish Parliament and the Welsh Assembly. 


\section{Bibliography}

ANDREWS, Leighton. Wales Says Yes. The Inside Story of the Yes for Wales Referendum Campaign. Bridgend: Seren, 1999, 222 p.

DENVER, David. 'Voting in the 1997 Scottish and Welsh Devolution Referendums: Information, Interests and Opinion', European Journal of Political Research, vol. 41, 2002, pp. 827-843.

GREAT BRITAIN SCOTTISH OFFICE. Scotland's Parliament. Cmnd. 3658, London: H.M.S.O., 1997, 43 p.

GREAT BRITAIN WELSH OFFICE. A Voice for Wales. Cmnd. 3718, London: H.M.S.O., 1997, 80 p.

JONES, J. Barry \& BALSOM, Denis. The Road to the National Assembly for Wales. Cardiff: University of Wales Press, 2000, 293 p.

JONES, Peter. 'A Start to a New Song: the 1997 Devolution Referendum Campaign', Scottish Affairs, vol. 21, 1997, pp. 1-16.

JONES, Richard Wyn \& LEWIS, Bethan. 'The Welsh Devolution Referendum', Politics, vol. 19, n 1, February 1999, pp. 37-47.

LABOUR PARTY. Because Britain Deserves Better, London: Labour Party, 1997, $40 \mathrm{p}$.

McAlLISTER, Laura. 'The Welsh Devolution Referendum: Definitely, Maybe?', Parliamentary Affairs, vol. 51, n 3, 1998, pp. 149-165.

PATTIE, Charles, DENVER, David, MITCHELL, James \& BOCHEL, Hugh. 'The 1997 Scottish Referendum: an Analysis of the Results', Scottish Affairs, vol. 22, 1998, pp. 1-15.

SCOTLAND FORWARD. Winning Scotland's Parliament. Edinburgh: Scotland Forward, 1998, 28 p.

SCOTTISH CONSTITUTIONAL CONVENTION. Towards Scotland's Parliament, Edinburgh: Scottish Constitutional Convention, 1990, 20 p.

SCOTTISH CONSTITUTIONAL CONVENTION. Scotland's Parliament, Scotland's Right, Edinburgh: Scottish Constitutional Convention, 1995, 36 p.

TAYLOR, Bridget \& THOMSON, Katarina (eds.). Scotland and Wales: Nations Again? Cardiff: University of Wales Press, 1999, 244 p.

WALES LABOUR PARTY. Shaping the Vision. A Report on the Powers and Structure of the Welsh Assembly, Cardiff: Wales Labour Party, 1994, 18 p.

WALES LABOUR PARTY. Preparing for a New Wales. A Report on the Structure and Workings of the Welsh Assembly, Cardiff: Wales Labour Party, 1996, 14 p. 